\title{
RAAMWERK VIR DIE ONTWIKKELING VAN 'N 4-DIMENSIONELE TEORIE VAN MENSLIKE GEDRAG
}

\author{
I. VAN W. RAUBENHEIMER
}

DEPARTEMENT BEDRYFSI ELKUNDE

UNIVERSITEIT VAN STELLENBOSCH

SUMMARY

Directives for the development of a 4-dimensional theory of human behaviour are formulated and discussed. The 3 spatial dimensions length, height and depth, and time are used as points of departure from which psychic analogues are defined as fundamental constructs of human behaviour. The psychological sphere described by these 3 psychic dimensions together with orientation towards time are then used as a basis of typifying and classifying human behaviour. Possibilities for the further development and validation of the theory as well as some of its practical applications are discussed.

\section{AGTERGROND}

Een van die grootste kwellinge van die vakwetenskaplike van die moderne tyd is, ironies genoeg, die oorweldigende hoeveelheid kennis wat daagliks vrygestel word deur vakgenote oor die hele wêreld. In 'n poging om in 'n see van kennis wat so ontstaan 'n vastrapplek te kry, het wetenskaplikes hul begin wend tot spesialisasie en steeds verdere spesialisasie in so 'n mate dat integrasie van kennis en dus ware wetenskapsbou bykans onmoontlik geraak het.

Die koppeling van eenhede van gespesialiseerde kennis om sodoende uiteindelik 'n geïntegreerde sisteem van kennis te bou, is die hoofdoel van wetenskapsbeoefening. Die moontlikheid tot die bereiking van hierdie doel lyk egter al hoe skraler namate kennis en spesialisasie op 'n al hoe wyer front toeneem.

Integrasie cum spesialisasie as 'n benadering tot wetenskapsbou bied vanweë die prakties-moeilik-uitvoerbaarheid daarvan slegs 'n gedeeltelike oplossing vir die probleem. Ander aanvullende benaderings tot ' $n$ integrasie van kennis en dus tot wetenskapsbou behoort daarom ondersoek te word. 
Een sodanige benadering kom neer op 'n herevaluering van die rol van teoriebou in wetenskapsbeoefening. Die geskiedenis van die Sielkunde openbaar interessante opeenvolgende benaderinge tot teoriebou en die gebruik wat oor die dekades heen van teorieë gemaak is (Boring, 1954). Waar aktiwiteite in die Sielkunde in die beginjare hoofsaaklik gesentreer het om globale teorieë (en later skole) het hierdie teorieë hul rigtinggewende krag met die verloop van die dekades al hoe meer begin verloor. In die plek daarvan het kleiner mikroteorieë gekom oor kleinere aspekte van menslike gedrag wat met "n groter mate van eksperimentele sofistikasie en akkuraatheid nagevors en geverifieer is. Dit het inderdaad diepgaande kennis van brokstukke van menslike gedrag voorsien, maar vir die sielkundige het dit skynbaar al hoe moeiliker geword om sy wetenskaplike greep op menslike gedrag as geheel te verstewig - iets wat die ouer teorieë probeer verwesenlik het.

Hierdie versplintering van kennis a.g.v. spesialisasie is nie net 'n probleem van die vakwetenskappe, waarvan die Sielkunde een is, nie. Dit is trouens ook die krisis (aldus Stoker, 1969) waarin die moderne universiteit as generator van nuwe kennis hom bevind.

Die waarde van teoriebou moet egter nie onderskat word nie. Dit wil trouens voorkom asof ' $n$ moontlike oplossing steeds geleë is in teoriebou as sodanig, hoewel 'n andersoortige oriëntasie daartoe nodig geword het. Waar die globale teorieë van ouds wetenskaplike aktiwiteite in bepaalde verkenningsrigtings gestuur het en die mikroteorieë van later jare groter, diepgaander kennis (maar los van 'n bepaalde struktuur of raamwerk) gebring het, behoort kontemporêre teorieë daarop ingestem te wees om raamwerke en strukture daar te stel waarbinne bestaande kennis op 'n hanteerbare wyse geklassifiseer en gerangskik kan word. Sodanige teorieë kan beskrywenderwys na verwys word as integrerende klassifikasieteorieë. Die inbind van kennis in ' $n$ logiese, hanteerbare sisteem is trouens ' $n$ meer gevorderde (finale?) trap op die ewolusieleer van teoriebou. Dit is ooglopend hierdie soort van teorie wat Marx (1966) in gedagte het wanneer hy verklaar dat (p.6) .... "theories integrate and order existing empirical laws, independently of their own degree of logical sophistication .... theory is useful because it provides an economical and efficient means of abstracting, codifying, summarizing, integrating and storing information."

Omdat die funksie van so 'n integrerende klassifikasieteorie van ' $n$ besondere aard is, is die benadering tot die bou daarvan en ook die norme aan die hand waarvan dit beoordeel moet word, nie die gebruiklike nie. Marx (1966, p.13) maak 'n onderskeid tussen sogenaamde ontdekkingsteorieë en bevestigingsteorieë wat in hierdie verband ter sake is. Onder laasgenoemde verstaan hy teorieë wat aan die hand van operasioneel gedefinieerde hipoteses 
empiries getoets word. Eersgenoemde verwys na uitgangspunte en postulate wat weliswaar nie onmiddellik empiries verifieerbaar is nie, maar wat nuwe perspektief gee en kan lei tot kreatiewe formulerings van navorsingsprobleme.

Die ontdekkingsbenadering tot teoriebou het egter dié implikasie dat daar noodwendig met minder natuurlike, minder lewensgetroue konsepte gewerk word. Dit is onvermydelik en weliswaar 'n logiese uitvloeisel van die benadering aldus Pratt (a.w. p.12). Dit kan ook as 'n voordeel volgens Thouless (1949) beskou word aangesien bekende, populêre terme dikwels valse begrippe tuisbring. Hierdie lewensgetrouheidsnorm is klaarblyklik nie 'n voorvereiste vir teoriebou nie. Spence (1944) is ook van mening dat hoe hoër die vlak van abstraksie in teoriebou, hoe beter die begrip en uiteindelike voorspelling van en beheer oor gedrag. 'n Voorwaarde wat egter hieraan gekoppel behoort te word is dat daar in die teoriebouproses beweeg sal word van 'n sogenaamde hipotetiese konstruk (met min operasionele klaarheid) na 'n konstruk (intervening construct - ala Marx, 1966, p.189) met soveel moontlike operasionele geldigheid. Die strewe moet dus steeds eksplisitering en kwantifisering van gedragskorrelate van die konstruk wees. Konstrukte wat op konseptuele vlak bly, dit wil sê sonder dat die wetenskaplike die konsekwensies daarvan vir gedrag in operasionele terme uitspel, neem 'n al hoe geringer plek in die ontwikkeling van die gedragswetenskappe in - trouens, dit hoon die eise wat teenswoordig aan die ontwikkeling van die wetenskap gestel word.

Hoewel belangrik en oortuigend moet in hierdie verband egter daarop gewys word dat blote (dikwels eenmalige) empiriese bevestiging van 'n teorie nie die enigste aanduiding van die geldigheid daarvan is nie. Die metodes van sintuiglike waarneming, van definisie, van klassifikasie, van deduksie en induksie, van analise en sintese en van verstaan en verklaar behoort almal sover moontlik in samehang met die hipotese-verifiërende induktiewe metode gebruik te word. Stoker (1969, pp.106-107) wys op die begrensde geldigheid van wetenskaplike metodes en beklemtoon die feit dat wetenskaplike metodes in wese aan mekaar diensbaar is (en dus diensbaar gemaak moet word) omdat elk slegs sekere fasette van die kenbare toelig.

Die vertrekpunt in teoriebou, naamlik die hipotetiese konstruk, is nie sonder aanloop nie. Dit kan die resultaat wees van 'n induktiewe proses waarvolgens elemente van menslike gedrag saamgevoeg en die essensie daarvan geabstraheer word. Dit kan egter ook die resultaat wees van 'n deduktiewe proses. Die beginpunt van die deduktiewe proses kan, in die ontwikkeling van 'n integrerende klassifikasietoerie, onder andere selfewedente waarhede aangaande menslike gedrag wees óf dit kan basiese beginsels wees wat reeds deur ander vakwetenskappe (bv. die Chemie, Fisika of Medisyne) ondersoek en blootgelê is. 
'n Verdere kenmerk van 'n integrerende klassifikasieteorie is dat dit so eenvoudig moontlik moet wees. Die bou van so 'n teorie sal dus die eenvoudigheidsbeginsel ("law of parsimony") moet bevredig. Dit wil sê, "daar mag nie meer verklaringsbeginsels aanvaar word as wat nodig is nie" (Stoker, 1969, p.161). Aan die anderkant mag die verskeidenheidsbeginsel, dit wil sê, "daar mag nie minder verklaringsprinsipes aanvaar word as wat noodsaaklik is nie" (a.w. p.161) nie geweld aangedoen word nie.

Samehangend met die sogenaamde ontdekkingsbenadering wat as ' $n$ kenmerk van die integrerende klassifikasieteorie beskou kan word, is die verdere kenmerk dat konsepte wat daarin gebruik word, noodwendig "surplusbetekenis" (ala Marx, 1966, p.30) sal hê. Dit besweer natuurlik 'n belangrike beginsel van teoriebou, naamlik dat alle konsepte operasioneel gedefinieer moet wees. Laasgenoemde beginsel is van kardinale belang by die sogenaamde bevestigingsbenadering tot teoriebou, terwyl dit in die ontdekkingsbenadering noodwendig 'n ondergeskikte vereiste word.

Teen die voorafgaande as agtergrond, word daar nou in die volgende gedeeltes 'n poging aangewend om 'n raamwerk te formuleer waarbinne 'n integrerende klassifikasieteorie van menslike gedrag ontwikkel kan word.

\section{AANLOOP TOT 'N 4-DIMENSIONELE TEORIE VAN MENSLIKE GEDRAG}

In 'n poging om 'n raamwerk vir die ontwikkeling van 'n 4-dimensionele klassifikasieteorie van menslike gedrag daar te stel, word sekere kernbegrippe aan die natuurwetenskappe ontleen.

Hierdie bepaalde benadering het as grondtoon die primêre beskouing dat die kosmos volgens basiese wette funksioneer, dat hierdie wette vir die hele kosmos geld en dat die mens deel is van die kosmos. Wette wat dus vir die res van die kosmiese verskeidenheid (stof, plant en dier) geld en wat reeds deur die natuurwetenskappe blootgelê is, mag dalk ook van toepassing wees op menslike gedrag.

Die gedagte dat die (ouer) natuurwetenskappe 'n invloed kan (en selfs behoort) uit te oefen op benaderings tot die (jonger) geesteswetenskappe (spesifiek sielkundige wetenskappe) is opsigself nie nuut nie. In hierdie verband skryf Hall en Lindsay, (1957, p.206); "The older sciences of physics and chemistry have often influenced the course of newer sciences like psychology by furnishing them ways of thinking about and conceiving of natural phenomena it is almost inevitable, considering the basic unity of all sciences 
that they should be taken over by the less mature sciences and applied in their special provinces". En verder: "It should be pointed out however, .... that it is the method of representing reality and not the actual physical concepts themselves that has been incorporated into psychology".

Hoewel die gedagte om in die proses van teoriebou in die gedragswetenskappe aanknopingspunte by byvoorbeeld die natuurwetenskappe te soek minder konvensioneel is, maak dit sin in die lig van die eenheid van die kosmos en die selfewidente waarheid dat stof, plant, dier en mens aan die kosmiese wetsorde onderworpe is. Trouens, die mens is self deel daarvan. (Vergelyk in dié verband Stoker, 1969, pp.199-236 se bespreking van die kosmiese wetsorde.) Die kosmiese wetsorde is gegewe; dit word nie deur die wetenskaplike geskep nie. Sy taak is bloot die ontdekking daarvan - die ontdekking dus van die wette wat die gedrag van stof, plant, dier en mens bepaal en reguleer. "Die wet (resp. wetsorde) wat hy (wetenskaplike) ontdek en formuleer behoort ooreen te stem met die wet (resp. wetsorde) van die kosmiese sélf. Hy moet sy bevindings telkens weer aan die kosmos sélf verifieer" (Stoker, 1969, p.203).

'n Belangrike kenmerk van die kosmiese wetsorde (waaronder stof, plant, dier en mens val) vir die doel van hierdie bespreking, is dat dit onveranderlik (vas) is (op.cit., p.205). Die wette wat dus vir onder andere menslike gedrag geld, staan vas en is onveranderlik. Die kosmiese wette wat menslike gedrag bepaal is daarom nie veranderbaar deur menslike ingryping of formulering nie. (Hoewel hierdie beskouing dit moeilik maak om die invloed van oorerwing en omgewingsveranderlikes en die omvang van individuele verskille te begryp, moet daarop gewys word dat die gelding van die kosmiese wette vir menslike gedrag op 'n ander (hoër) vlak van abstrahering opereer waar individuele verskille akkommodeerbaar is sonder om enige kosmiese wetmatigheid te versteur).

'n Verdere kenmerk van die kosmiese wetsorde is dat hoewel elke radikaal onderskeie groepe wette (bv. ekonomiese vs. psigiese wette) soewerein in eie kring is en dus nie tot mekaar herleibaar is nie, is alle wette onderling verbind en is die samehang van wette in die kosmiese wetsorde onverbreeklik. Wette wat dus vir stof, plant, dier en mens geld, vorm 'n harmoniese geheel. 'n Eenheid dus, maar sonder dat dit wedersyds direk toepasbaar gemaak kan word.

In die soeke na 'n basiese raamwerk waarbinne menslike gedrag geklassifiseer kan word, word daar van die standpunt uitgegaan dat die mees fundamentele determinante van menslike gedrag geïdentifiseer behoort te word en dat ervaringe in die eerste lewensdae (jare) dalk hierdie fundamentele bepalers van gedrag mag aanstip. Daar word verder gepostuleer dat 
hierdie determinante van die mens se vroegste belewenisse hul oorsprong in die fisiese ruimte rondom die individu het. Dit vorm die raamwerk waarbinne hy as mens funksioneer. Sy sintuie (gehoor, gesig, gevoel, smaak en reuk) funksioneer noodwendig binne hierdie raamwerk. Dit trek die buitelyne, die limiete, van sy ervaringe as mens. Dit wil dus voorkom of hierdie raamwerk die ankerpunte van menslike ervaringe (belewenis) is en dat die beskrywing daarvan (struktuur) sowel as die bepaling van die determineringswaarde (funksionaliteit) daarvan vir 'n begrip van menslike gedrag essensieel is.

Die belewenis van die pasgeborene is van meet af dus ' $n$ belewenis binne ' $n$ bepaalde fisiese ruimte wat as sodanig stimuli verskaf vir sy reaksies. Hy leer die dimensies van hierdie fisiese ruimte ken en in 'n bepaalde sin vorm dit verlengstukke van homself. Dit kry vir hom mettertyd ook psigologiese betekenis. In sy denkprosesse beweeg die individu as't ware rond binne ' $n$ psigologiese ruimte en die posisie wat hy in hierdie ruimte inneem behoort beskryf te kan word in terme van die koördinate van daardie ruimte.

Enige fisiese ruimte word beskryf deur die Cartesiaanse koördinate van lengte/diepte, breedte en hoogte. Die moontlikheid bestaan nou dat hierdie koördinate of dimensies wat die fisiese ruimte beskryf mettertyd vir die individu psigologiese betekenis kry en dat daar vir elke fisiese dimensie 'n psigiese analoog ontwikkel - sodat die mens se gedrag (nie fisiese beweging nie) beskryf kan word in terme van psigiese dimensies van diepte, breedte en hoogte. Soos wat die mens se posisie in 'n fisiese ruimte bepaal kan word of beskryf kan word deur die drie koördinate - dit wil sê, sy plek in 'n fisiese ruimte word daardeur aangedui - so kan sy posisie (psigologies) in 'n psigologiese ruimte of sfeer deur die drie psigiese koördinate aangedui word.

In hierdie benadering waarvolgens die mens se beleweniswêreld beskryf word na analogie van die koördinate van fisiese ruimte, is dit belangrik om daarop te wys dat die psigiese koördinate nie 'n spieëlbeeld van die fisiese koördinate is nie. Die mens se posisie in die fisiese ruimte word nie in die psigologiese ruimte geregistreer nie. Geen dualisme dus van fisiese en psigiese wêreld soos wat Fechner (Boring, 1954) en latere psigofisici probeer demonstreer nie.

Die psigologiese ruimte is eerder ' $n$ analoog van die fisiese ruimte en as sodanig toon dit ooreenkoms. Hierdie ooreenkoms is egter nie een van gelykheid nie, maar van eendersheid. Soos wat 'n portret 'n afbeelding van die werklike is, so is die psigologiese ruimte ' $n$ afbeelding van die fisiese ruimte. Dit kom ooreen daarmee, en in hierdie bepaalde verband het dit as't ware daaruit gegroei, maar dit is nie dieselfde nie. 
Die ruimtelikheid (of sfeer) van die fisiese model en die koördinate wat dit beskryf, word as fundamentele konsepte oorgedra na die psigologiese wêreld - omdat die psigologiese wêreld sy ontwikkeling begin en voortsit binne die limiete en ooreenkomstig die struktuur van die fisiese ruimte. Die fisiese ruimte en die koördinate wat dit beskryf word dus afgeets op die beleweniswêreld van die individu, sy beleweniswêreld word daarvolgens gepatroneer. Die individu word gewoond daaraan om sy psigologiese ruimte te visualiseer soos wat hy sy fisiese ruimte ervaar.

Die beweging in die psigologiese ruimte veronderstel egter 'n tendens. Op elk van die psigologiese koördinate beweeg die mens op 'n tipiese wyse sodat hy altyd min of meer dieselfde posisie in die psigologiese ruimte sal inneem. Die posisie wat hy inneem bepaal sy persoonlike styl of tipiese gedrag of optrede. Dit impliseer dat die posisies op die psigiese dimensies, waarop die individu beweeg, deurgaans min of meer dieselfde sal wees. (Uiteraard sal daar individuele verskille wees en individuele veranderlikheid van beweging op elke dimensie wat, soos later aangedui word, in berekening gebring moet word).

Die beskouing dat die psigologiese ruimte uit ervaring en interaksie met die fisiese ruimte ontwikkel, is suiwer empiries. Die psige ervaar van geboorte af die grense/raamwerk waarbinne dit moet/kan opereer via die liggaam. Daar is nie 'n interaksie tussen psige en liggaam in hierdie proses nie soos Descartes se dualisme leer nie (Herrnstein en Boring, 1966, p.581) ook nie 'n parallelle vooraf bepaalde harmonie nie, soos deur Leibnitz voorgestel nie (a.w. p.582). Dit gaan nietemin nie om die houdbaarheid al dan nie van dualisme parallelisme nie. Veel eerder gaan dit om 'n begrensing (ruimtelike afbakening) van die psigologiese sfeer via die ervaring van die liggaam in sy fisiese ruimte.

Hierdie siening verskil van Descartes (a.w. p.583) omdat laasgenoemde erkenning gee aan aangebore ("innate") idees soos byvoorbeeld die begrip van tyd, ruimte, getalle, die self ens. Dit kom nader aan Locke se standpunt dat ervaring die enigste bron van alle psigiese inhoud is. Hierby sluit Berkeley se siening (a.w. p.585) ook aan, naamlik dat die idee van ruimte opgestel word uit ervaring met visuele- en tassensasies. Ook Ewald Hering (a.w. pp.148-151) se nativistiese teorie van visuele ruimtelike waarneming sluit hierby aan. Volgens Hering het elke retinale punt drie ruimtelike kwaliteite, naamlik hoogte, breedte en diepte. Ruimtelikheid is dus gegewe, maar ruimtelike waarneming kom deur ervaring. Die oriëntasie van die "Ek" m.b.t. hoogte, breedte en diepte kom deur ervaring. 
Dusver is slegs aandag geskenk aan die drie ruimtelike dimensies en hul psigiese analoë. Die vierde dimensie naamlik tyd word ook uit die fisiese wetenskappe oorgeneem met as psigiese analoog daarvan, tydoriëntasie.

Die mens se oriëntasie tot tyd kan, soos later breedvoeriger aangedui sal word, terugherlei word tot 'n fundamentele oriëntasie tot alle groei, ontwikkeling, voortgang, verandering d.w.s. tot die essensie van die lewe self. As sodanig is die klassifikasie van individue volgens tydoriëntasie vir die doel van die 4-D teorie essensieel. Dit mag wees dat 'n verskil in tydoriëntasie die mees fundamentele (betekenisvolle) verskil aandui tussen individue, groepe, kulture en volke. Hierdie besondere postulaat is uiteraard tentatief en vereis verdere logiese fundering. Vir die doeleindes van hierdie bespreking word dit egter voorlopig as aanname gebruik.

\section{DIE TIPERING VAN POSISIES BINNE DIE PSIGOLOGIESE RUIMTE}

Soos vir die bepaling van enige posisie binne ' $n$ fisiese ruimte of sfeer, van die Cartesiaanse koördinaatstelsel gebruik gemaak word, kan die Cartesiaanse koördinaatsisteem ook gebruik word om 'n bepaalde individu se posisie in 'n psigologiese sfeer te bepaal. Dit veronderstel dat daar vir die individu op elkeen van die drie dimensies of koördinate 'n posisie of lesing bepaal sal word. Elkeen van die drie dimensies verteenwoordig 'n dimensie of konstruk van menslike gedrag. Die posisie van die individu op elk van die drie koördinate sal dus bepaal word deur sy tellings op meetinstrumente wat die verskillende psigiese dimensies of konstrukte meet. (Dit veronderstel uiteraard dat elk van die drie konstrukte of dimensies betroubaar en geldig gemeet sal word. Later word hierop breedvoeriger ingegaan.)

'n Besondere bepaling van die Cartesiaanse koördinaatsisteem is dat die drie asse loodreg op mekaar ingestel is, of anders gestel, dat die asse waar dit by die kern van die sfeer kruis, reghoeke vorm. Dit veronderstel dus ook dat die dimensies of koördinate van die psigologiese sfeer ortogonaal sal wees en dat die konstrukte wat dit verteenwoordig dus nie met mekaar sal korreleer nie.

In die Cartesiaanse koördinaatsisteem kan ook voorsiening gemaak word vir 'n nulpunt waar die drie koördinate ontmoet of kruis. Die nulpunt in die psigologiese ruimte is van kardinale belang. Dit vorm die mees fundamentele verwysingspunt in die psigologiese sfeer waarheen enige punt in die drie dimensionele ruimte of enige posisie in die sfeer geprojekteer kan word. Die nulpunt van die psigiese assestelsel word geneem as 'n punt waar die drie 
gemiddeldes van 'n bepaalde normgroep kruis. Hierdie normgroepe kan wees sekere beroepgroepe, sosio-ekonomiese groepe, religieuse groepe, geslagte, rasse, ouderdomsgroepe en so meer. Enige individuele afwyking van hierdie normgroepgemiddeldes, positief en negatief, sou dan op die drie asse aangebring word. 'n Individu sou dus aan die hand van sy "prestasie" op die drie meetinstrumente enige posisie in die sfeer kon inneem.

Die berekening van die gemiddeldes vir 'n normgroep het die volgende ramifikasies waarop hier kortliks gelet moet word. In die eerste plek sou die normgroep self noukeurig omskryf moet word (bv. suksesvolle bestuurders in 'n finansiële instelling). Die rekenkundige gemiddelde van die prestasies van die bestuurders op elkeen van die drie skale wat die drie dimensies (konstrukte) meet, word dan gelyk gestel aan 0 (d.w.s. uitgedruk in standaardtellings) wat ooreenstem met die nulpunt of kern van die assestelsel. 'n Bepaalde individu se telling op die drie metingskale word op dieselfde wyse in standaardvorm uitgedruk en op die assestelsel geprojekteer. Die posisie wat hy dan in die sfeer inneem sal aandui in hoe 'n mate hy van die algehele nulpunt van die assestelsel afwyk en dus ook van die normgroep. Die volgende skematiese voorstelling beeld so 'n moontlike posisie uit:

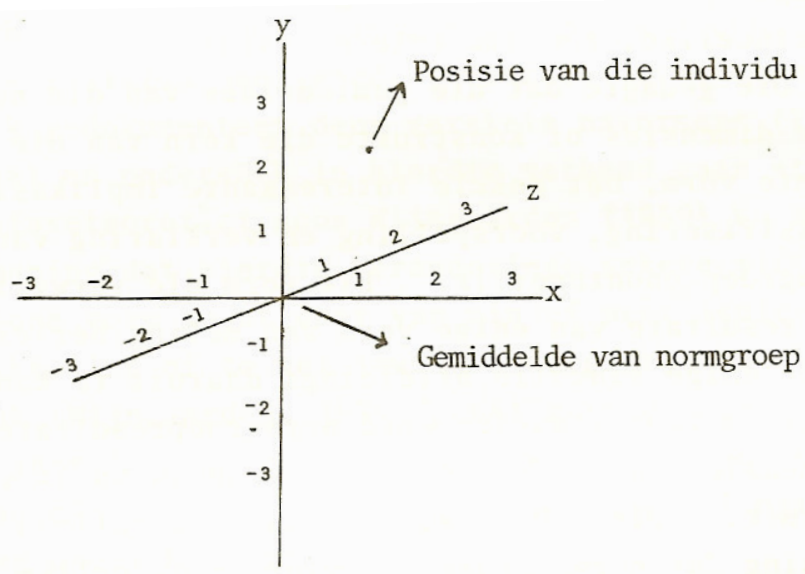

Die afstand wat 'n individu van die nulpunt af inneem kan gekwantifiseer word met behulp van die volgende formule.

$\mathrm{d}=\sqrt{\mathrm{x}^{2}+\mathrm{y}^{2}+\mathrm{z}^{2}}$ waar

$\mathrm{d}=$ afstand tussen normgroep en individu

$\mathrm{x}, \mathrm{y}$ en $\mathrm{z}=$ standaardtellings van die individu op die onderskeie dimensies (asse)

Die benadering met betrekking tot normvergelyking is streng empiries. Daar word van die veronderstelling uitgegaan dat die normgroep die ideale groep is. Die mate van sukses wat byvoorbeeld die bestuursgroep verteenwoordig, verteenwoordig die grootste mate van sukses 
wat in die bepaalde omgewing (finansiële instelling volgens ons voorbeeld) moontlik is. Dieselfde redenasie is van toepassing op alle ander moontlike normgroepe. Die algehele gemiddelde van die normgroep is die uiteindelike, fundamentele maatstaf.

Die gedagte dat die gemiddeldes van die normgroep op die drie dimensies of konstrukte die kern van die psigologiese ruimte vorm, het enkele interessante implikasies. Vir die klassifisering, voorspelling en verklaring van gedrag is die normgroep onontbeerlik. Dit vorm die verwysingspunt waarheen die resultate van enige vorm van meting herlei moet word ten einde enige sinvolle afleidings daaruit te kan maak. In die meeste metingsituasies word normgroepresultate slegs op een "dimensie" van gedrag verkry en dan as basis van vergelyking gebruik. Die 4-D-benadering maak nie alleen daarvoor voorsiening dat normwaardes vir vier afsonderlike (onafhanklike) dimensies van gedrag bepaal word nie, maar ook dat hierdie normwaardes in kombinasie gebruik word ten einde die individu se posisie in die psigologiese ruimte, relatief tot sy normgroep te bepaal. Omdat daar van die standpunt uitgegaan word dat die vier konstrukte die mees fundamentele dimensies van menslike gedrag verteenwoordig, is dit wenslik dat die normgroep só gekies sal word dat dit die grootste moontlike vergelykingskrag sal hê. Met vergelykingskrag word bedoel die relevantheid of sinvolheid van 'n vergelyking met die normgroep.

As dit in aanmerking geneem word dat die mens ' $n$ immer ontwikkelende/veranderende wese is en dat daar in die beoordeling van menslike gedrag in die alledaagse lewe groot waarde geheg word aan die stadium van ontwikkeling (gewoonlik uitgedruk in kronologiese ouderdom) waarin die individu verkeer, dan lê dit voor die hand dat stadia van ontwikkeling vir die definiëring van normgroepe in berekening gebring behoort te word. Vaardighede, vermoëns, belangstellings, waardes, verander namate die individu ouer word. Hierdie veranderinge is reeds deeglik gedokumenteer deur verskeie navorsers (Tyler, 1965, pp.271298) en ondersoek in hierdie verband gaan steeds voort. Lewensfaseteoretici soos Wijngaarden (1959) en Bühler (1959) is van mening dat hierdie veranderinge sekere min of meer vaste patrone vorm sodat daar van min of meer isoleerbare fases van ontwikkeling of te wel lewensfases gepraat kan word. Volgens Waterink (Wijngaarden, 1959, p.64) gaan die mens ongeveer elke sewe jaar 'n nuwe fase van ontwikkeling binne en dat die een fase van die ander in terme van 'n aantal belangrike vorme van gedrag onderskeibaar is.

Indien Waterink se lewensfases as uitgangspunt geneem word (en dit maak intuïtief heelwat sin) kan elk van die lewensfases as 'n afsonderlike normgroep beskou word. Toegepas op die 4-D-raamwerk sou dit daarop neerkom dat die gemiddelde "prestasie" op elkeen van 
die vier konstrukte vir elke lewensfasegroep bereken word. Die posisie wat enige bepaalde individu in die psigologiese ruimte inneem, sal dan vergelyk word met die assestelsel wat vir sy bepaalde lewensfasegroep geld.

Die gebruik van lewensfasegroepe as normgroepe hou velerlei moontlikhede in vir die beoordeling en voorspelling van gedrag. Indien ' $n$ bepaalde individu byvoorbeeld 'n posisie in die psigologiese ruimte inneem wat relatief ver weg van die kern daarvan is, bestaan die moontlikheid dat indien hy op die assestelsel van 'n volgende lewensfasenormgroep geprojekteer word, hy nader aan die kern dáárvan kan wees. Hieruit sou moontlik afgelei kon word dat die individu sy groep "vooruit is" en in situasies (opvoedkundig, sosiaal, beroeps) geplaas behoort te word waar daar erkenning aan sy gevorderde ontwikkeling gegee sal word - met al die voordeel vir die individu en die gemeenskap wat daaruit te trek is.

Die afstand tussen die individu en 'n groep kan aan die hand van die formule bereken word soos vroeër uiteengesit.

Tot dusver in die tiperingsproses was daar veral van drie dimensies sprake. Die vierde dimensie naamlik tydoriëntasie word in die tiperingsproses egter as 'n primêre eerste-orde maatstaf van klassifikasie beskou. Die rede hiervoor is nie alleen dat ' $\mathrm{n}$ 4-dimensionele tipering konseptueel moeilik is nie. Dit hang ook saam met die vermoede (postulaat op hierdie stadium) dat tydoriëntasie as vierde dimensie 'n meer fundamentele bepaler van menslike gedrag is - soos later breedvoeriger gemotiveer sal word. Voldoende is dit om op hierdie stadium te suggereer dat 'n verskil in tydoriëntasie (tussen individu en individu, tussen individu en normgroep en tussen verskillende groepe) 'n belangriker, meer fundamentele, verskil sou wees as 'n verskil in posisie binne die psigologiese ruimte of sfeer. Bo en behalwe die bepaling van ' $n$ posisie in die psigologiese sfeer sou alle individue (en ook groepe ter sprake) in terme van tydoriëntasie geklassifiseer behoort te word. Tyd as dimensie word dus in die sisteem betrek deur dit te gebruik as 'n basiese klassifikasiedimensie. Elke individu word vooraf volgens sy tydoriëntasie geklassifiseer. Binne die raamwerk van 'n bepaalde tydoriëntasie tree die ander drie dimensies dan in werking. 'n Bepaalde individu sal dus eers volgens sy tydoriëntasie geklassifiseer word en daarna word sy posisie in die Cartesiaanse (psigologiese) ruimte bepaal. Hier is m.a.w. sprake van die posisie van 'n individu in die psigologiese ruimte en daarnaas sy bepaalde tydoriëntasie.

Die identifisering van die posisie wat ' $n$ individu in die psigologiese ruimte inneem maak dit moontlik om die sfeer in verskeie subsfere in te deel. Die eenvoudigste sisteem sou wees waar elke as uit twee dele bestaan - bo die gemiddelde en onder die gemiddelde van die 
normgroep. Dit gee sodoende 'n totaal van vier kwadrante of subsfere. (Wanneer individuele veranderlikheid in berekening gebring word, sal individuele posisies in die ruimte egter nie deur ' $n$ bepaalde punt beskryf word nie, maar deur 'n subruimte binne enigeen van die kwadrante.) ' $n$ Bepaalde individu sou volgens hierdie basiese indeling in enigeen van 4 subsfere geplaas kan word. Wanneer tydoriëntasie in berekening gebring word en daar sou byvoorbeeld vier basiese tydoriëntasies omlyn kon word, kom dit op 'n sisteem van sestien kategorieë neer $(4 \times 4=16)$. Elkeen van hierdie sestien kategorieë behoort 'n bepaalde tipe individu aan te dui, 'n tipe individu waarvan die tipiese gedrag omlynbaar en voorspelbaar kan wees. Op die wyse van tipering van individue binne elk van die kategorieë en die bruikbaarheid van die klassifikasiesisteem word later breedvoeriger ingegaan.

\section{NADERE OMSKRYWING VAN DIE 4 DIMENSIES}

Aangesien die vier dimensies die basiese eenhede van ontleding in die 4-dimensionele klassifikasieteorie is, is dit nodig dat elk van die dimensies of konstrukte van gedrag breedvoeriger omskryf en toegelig word.

Die diepte-dimensie

Diepte waarneming, in empiriese sin, het te make met die rangskikking van objekte in bepaalde (realistiese) verhoudings tot mekaar en tot die waarnemer daarvan. Hoe verder (dieper) waargeneem word, hoe moeiliker raak dit om (realistiese) verhoudinge tussen objekte waar te neem. Afstandskatting tussen die waarnemer en 'n voorwerp is bv. op 'n kort afstand ooglopend makliker as op ' $n$ lang afstand. So ook is die skatting van afstande tussen voorwerpe op 'n kort afstand makliker as op 'n lang afstand. Dit is vir die mens relatief moeilik om sy waarneming as't ware ver van hom af uit te stuur en nog akkuraat waar te neem. Dit kan redelikerwys aanvaar word dat daar ook individuele verskille sal wees in die gemak waarmee mense "uitbeweeg" op die diepte-dimensie om akkuraat waar te neem.

Die psigiese analoog van dieptewaarneming, dit wil sê beweging op die sielkundige diepte-dimensie veronderstel dat die individu homself "distansieer" of psigologies verplaas na situasies en omstandighede weg van hom. Hy beweeg dus uit na situasies, konstrueer dit vir homself suiwer (dit wil sê sonder vaaghede) in sy geestesoog en stel bepaalde verhoudinge tussen objekte en tussen homself en daardie objekte in die gekonstrueerde situasie op. Dit impliseer dat sy eie posisie in die gekonstrueerde situasie baie duidelik en realisties uitgebeeld word. So 'n konstruksie kan enige situasie uitbeeld en die figure daarin kan lewende en/of nie- 
lewende dinge wees. Dit kan 'n rekonstruksie van 'n fisiese (ruimtelike), psigologiese, maatskaplike, sosiale, mensverhoudings of beroepsituasie wees. Die gekonstrueerde situasie kan iets wees wat die persoon reeds ervaar het of dit kan 'n nuwe situasie wees waarin hy homself indink, of inleef.

Die psigologiese uitbeweeg na situasies impliseer dat die persoon ook sy eie plek, posisie en rol in die situasie sal bepaal en dat hy 'n sekere evaluasie van die belangrikheid en rol van elke objek in die situasie sal maak. Iemand wat maklik uitbeweeg op die dieptedimensie sou dus iemand wees wat homself maklik kan verplaas en in situasies kan indink of inleef. Dit wil voorkom asof dit aan die een kant 'n empatiese, meelewende persoon sou wees wat hom in andere se posisies en omstandighede kan indink, maar ook aan die anderkant iemand wat situasies en omstandighede daaraan gekoppel kan ontleed, akkuraat (realisties) kan opsom en dan ook sy besluite en optredes daarvolgens kan inrig.

In die gemak waarmee mense op hierdie psigologiese dieptedimensie beweeg sou redelikerwys ook individuele verskille verwag kan word. Sekere individue sou hulself dus makliker en vinniger kan verplaas en 'n relatief suiwerder, realistieser situasie kan konstrueer en hulself daarin kan indink. Andere sou weer minder geslaagd hierin wees. Diesulkes het 'n vaste ankerpunt of verwysingsraamwerk nodig waarbinne hul hul gedrag kan beplan. Hul gedrag is gekoppel aan die onmiddellike en verkieslik die waarneembare.

Beweging op die diepte-dimensie veronderstel nie abstrahering en beginselontleding van situasies nie. Laasgenoemde aktiwiteit val uitsluitlik op die psigologies hoogte-dimensie soos later aangedui sal word. Veel eerder verwys dit na 'n psigologiese beweeglikheid, 'n vermoë (of gewilligheid) om jouself los te maak van die onmiddellike omgewing en om situasies te antisipeer, te konstrueer en realistiese verhoudinge op te stel tussen jouself en objekte in die situasie en tussen objekte onderling.

Soos die ander dimensies, veronderstel beweeglikheid op die diepte-dimensie om 'n konstruk van menslike gedrag te wees wat 'n verskeidenheid van reeds bekende gedragsvorme behoort te akkommodeer of te omsluit en wat as sodanig spesifiek teoreties en empiries omlyn moet word. Teoretiese omlyning kom neer op 'n logiese koppeling tussen die konstruk en reeds bekende vorme van gedrag terwyl empiriese omlyning die meetbaarheid van die konstruk en sekere relasies daarvan met ander meetbare vorme van gedrag veronderstel.

Vir die meting van hierdie konstruk soos vir die ander, sou daar uiteraard oor die hele spektrum van metingstrategie in die Sielkunde gesoek moet word. Voorlopig wil dit egter 
voorkom asof een of ander vorm van selfrapport of selfbeskrywing 'n aanvaarbare vertrekpunt behoort te wees.

\section{Die breedte-dimensie}

Breedte in fisiese sin impliseer wydheid. 'n Breë venster, byvoorbeeld, beteken ook 'n wye venster. So ook beteken 'n breë pad 'n wye pad. Die teenoorgestelde van wydheid is enigheid of nouheid. Ook in die breedte-dimensie van die psigologiese ruimte lê 'n begrip van wydheid of omvang opgesluit. Soos wat die breedte-dimensie in die fisiese ruimte, wydheid, uitgestrektheid op horisontale vlak na links en na regs veronderstel - as die waarnemer as middelpunt of as uitgangspunt geneem word - so veronderstel breedte in die psigologiese ruimte ook wydheid of omvang op ' $n$ horisontale vlak. Die konseptualisering van 'n breedtedimensie in die psigologiese ruimte sou dus verder veronderstel, die individu se psigologiesebesigwees met 'n relatief wye of noue spektrum ('n bepaalde omvang dus) van begrippe, idees, gedagtes, kennis. Hy sal hom m.a.w. besig hou met 'n bepaalde verskeidenheid van dinge. Dinge van verskillende aard sal hom kon aanspreek. Hy sou geprikkel kon word deur onderwerpe op 'n wye (of nou) spektrum. Die wydheid van die spektrum is hier van belang. 'n Verdere bepaling is dat hierdie besig-wees op een (horisontale) vlak geskied. Dus, geen intellektuele kragte en geen eksistensie (buite homself beweeg) van die individu is hier ter sprake nie. Beweging op die breedte-dimensie van die psigologiese ruimte beskryf bloot die omvang van idees, begrippe, kennis (of intellektuele aktiwiteite), waarmee 'n bepaalde individu gewoonlik besig is. Beweging op die breedte-dimensie van die psigologiese ruimte impliseer dus 'n bepaalde omvang en verskeidenheid van psigiese aktiwiteite.

Dit lê voor die hand dat hierdie verskeidenheid die kosmiese verskeidenheid sal wees. Die mens leef binne die kosmos, hy is trouens, deel daarvan. Besigwees met iets veronderstel daarom besig wees met iets van die kosmiese verskeidenheid, naamlik stof, plant, dier of mens. Ten einde 'n greep te kry op die kosmiese verskeidenheid wat ons hier in gedagte het, word gebruik gemaak van die sogenaamde universele onderskeiding (of kosmiese dimensies) soos uiteengesit deur Stoker (1969, pp.161-189). Stoker identifiseer vier universele onderskeidings of kosmiese dimensies (Dooyeweerd (Stoker, a.w., p.160) noem dergelyke dimensies, dimensies van die menslike ervaringshorison) naamlik:

- Dimensie van modaliteite of voorstellingswyses

- Dimensie van individuele en sosiale strukture

- Dimensie van gebeurtenisse 
- Dimensie van waardes

Elkeen van hierdie dimensies is oorspronklik, d.w.s. dit weerspieël 'n bepaalde kant van die kosmos. Die een kosmiese dimensie is nie tot die ander herleibaar en in terme van die ander verstaanbaar nie. Enigeen van die dimensies gee 'n unieke en volledige oorskouing van die kosmos en verteenwoordig ' $n$ unieke ervaringshorison. Daar is egter ' $n$ besondere samehang van die dimensies (Stoker, 1969, p.164) in dié sin dat die een die ander veronderstel, maar in 'n bepaalde hiërargiese volgorde. So is die dimensie van waardes gefungeer in die dimensie van gebeurtenisse wat weer gefundeer is in die dimensie van individuele en sosiale strukture wat gefundeer is in die dimensie van modaliteite. Volgens hierdie hiërargie verteenwoordig modaliteite dus die mees fundamentele dimensie. Waar modaliteite verwys na voorstellingswyses (of handelingswyses volgens Stoker, op.cit., p.164) en die breedtedimensie van die psigologiese ruimte besig wees (handelingswyse) met iets (stof, plant, dier, mens) veronderstel, sou modaliteite (as een ervaringshorison van die mens volgens Dooyeweerd) goed gebruik kan word om die omvang of wydheid van die breedte-dimensie van die psigologiese ruimte te omskryf.

Stoker (op.cit., p.165) definieer 12 modaliteite, naamlik:

- Godsdiens (openbaring, geloof, diens van God)

- Die Sedelike (persoonsliefde, m.a.w. self- en naasteliefde)

- Die Juridiese (vergelding, die reg)

- Die Estetiese (die skone, harmonie)

- Die Ekonomiese (waardevereffening, behoeftebevrediging, besparing)

- Die Linguale (geartikuleerde openbaring van betekenis m.b.v. waarneembare tekens, bv. hoorbare klanke)

- Die Logiese (denke, afleiding, analise)

- Die Psigiese (bewussyn, gevoelsmatige)

- Die Biotiese (lewe)

- Die Fisiese (beweging, energie)

- Die Ruimtelike (dimensionale ekstensiteit)

- Die Aritmetiese (getal, diskrete kwantiteit)

Die verskillende modaliteite word ook modale wetskringe genoem. Dit oorspan die hele kosmos, d.w.s. stof, plant, dier en mens. Elke modaliteit is uniek en die een is nie tot die ander herleibaar of in terme van die ander verstaanbaar nie. Elkeen van die modaliteite is egter nie op stof, plant, dier sowel as mens van toepassing nie (Stoker, 1969, p.165). 
Wat die spesifieke aard of wese van elke modaliteit is, is nie altyd duidelik nie hoewel 'n bepaalde handelingswyse tog op self-ewidente wyse klassifiseerbaar is as behorende tot 'n bepaalde modale kategorie. Die mens se handelinge (besigwees) kan die sinskern of wese van enigeen van die 12 modaliteite verteenwoordig. Geen handelswyse (of besigwees) is moontlik wat nie as een van die 12 modaliteite geklassifiseer kan word nie. Die 12 modaliteite oorspan dus alle menslike handelinge. (Stoflike, plantlike en dierlike hoedanighede oorspan slegs 'n gedeelte soos aangedui in onderstaande skematiese voorstelling (aangepas uit Stoker, 1969, p.165).

Hoe meer modaliteite in die mense se handelingswyse weerspieël word, of anders gestel, in hoe meer modale kategorieë sy tipiese handelingswyse geklassifiseer kan word, hoe groter (wyer) is die omvang van sy psigologiese breedte-dimensie.

Vir die bepaling van 'n individu se posisie op die psigologiese breedte-dimensie sou dit dus noodsaaklik wees om 'n meetmiddel te ontwikkel wat die omvang van die mens se besigwees sal uitdruk in terme van die genoemde modale kategorieë. Tentatiewelik wi1 dit voorkom asof sy alledaagse (tipiese) handelingswyses ontleed en geklassifiseer behoort te word volgens die modale kategorieë. Aangesien daar 12 sodanige kategorieë omlyn is, blyk dit dat besigwees in 12 modale kategorieë 'n maksimumtelling sal verteenwoordig wat ' $\mathrm{n}$ individu in die onderhawige meetinstrument sal kan behaal. 
DIE KOSMIESE MODALITEITE

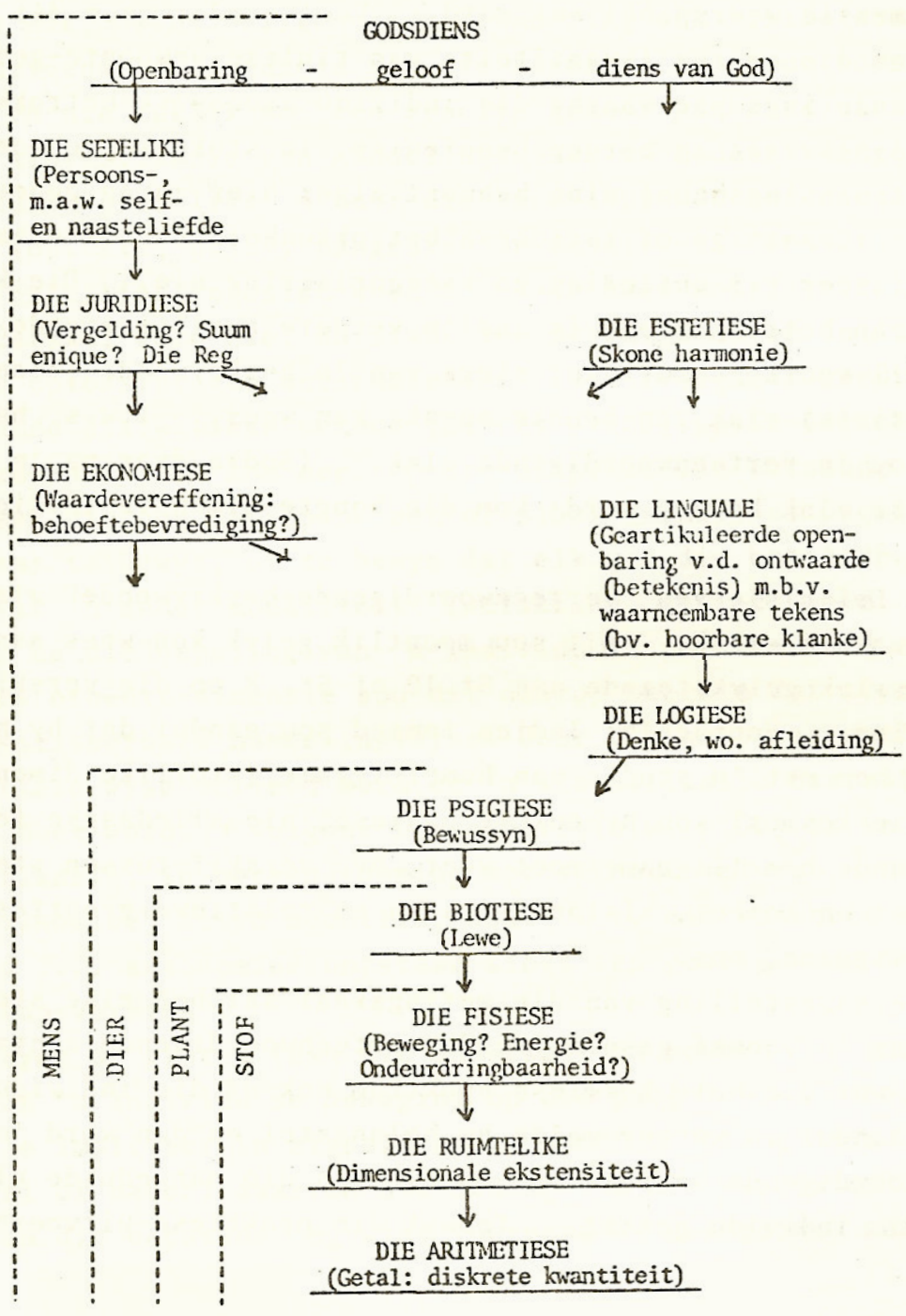

Graadverskille in die intensiteit van handelingswyse of besigwees behoort egter nie hier in berekening gebring te word nie, aangesien dit waarskynlik beter in die psigologies hoogtedimensie weerspieël sal word. Veel eerder gaan dit hier om die omvang (kwantiteit) van tipiese gewoonte-gedrag; die handelingswyse waarby die individu gewoonlik betrokke is. Handelingswyses in beroepsbeoefening, in stokperdjiebeoefening, in ontspanningsbeoefening behoort alger hier in ag geneem te word. Eenmalige of terloopse betrokkenheid sou uiteraard nie kwalifiseer vir ontleding en kategorisering nie. Die kwaliteit van betrokkenheid is dus ' $\mathrm{n}$ verdere kwalifiserende faktor. Dit wil voorkom asof hier slegs van 'n beskrywende (teenoor analitiese) vlak van kennis sprake kan wees. D.w.s. besig wees op 'n verteenwoordigende vlak. (Sodra daar na 'n analitiese vlak beweeg word, kom die hoogte-dimensie in die gedrang.) 
'n Definisie van "verteenwoordigende-beskrywende" vlak is uiteraard moeilik. Dit sou moontlik gelyk kon wees aan 'n kennisvlak gelykstaande aan St.10 of St. 8 op die verskillende terreine. Voorbeeld: Indien iemand sou aandui dat hy homself besig hou met 'n studie van hemelliggame (stoflike dimensie van die kosmos) sou hy enkele basiese, nie alledaagse feite aangaande hemelliggame moet weet, bv. verskil tussen ster en planeet en komeet, afstande tussen en relatiewe groottes van hemelliggame, ens.

Die samestelling van die metingskaal sal hoë eise stel. Dit kan 'n vooraf geselekteerde verteenwoordigende aantal items bevat wat die hele kosmiese spektrum dek of die individu kan eers aandui in watter velde hy belangstel en dan word 'n verteenwoordigende aantal vrae op elk van die aangeduide vlakke aan die individu gestel. Terwyl die praktiese uitvoerbaarheid van laasgenoemde benadering in 'n navorsingsopset nie baie hoog is nie, bevat eersgenoemde benadering ook risiko's aangesien verteenwoordigendheid van die kosmiese spektrum formidabel is en nie maklik met een vraelys gemeet kan word nie.

Die klassifikasie van handelingswyses in modale kategorieë is nietemin grootliks ' $\mathrm{n}$ voor-die-hand-liggende oefening aldus Stoker (op.cit., p.167) aangesien 'n modaliteit "intuïtief ontdek en intuïtief ingesien word". Waar twee modaliteite egter nie onderskei word nie, ontstaan teenstrydighede of antinomieë. Vir die oplossing van antinomieë of teenstrydighede word die sogenaamde dialektiese metode (Stoker, 1969, pp.58-60) aan die hand gedoen. Dit kom neer op die uitpluis van botsende stellings met die oog daarop om een of albei (almal) as ongeldig of onwaar te bewys, of te bewys dat elk van die botsende stellings vir 'n ander modaliteit (wetskring, gebied) geld. Verwysende na die bepaling van 'n individu se posisie in die psigologies breedte-dimensie sou dit daarop neerkom dat skynbaar onklassifiseerbare handelingswyses deur die navorser op 'n dialektiese wyse ontleed word en 'n klassifikasie daarvolgens gedoen moet word. Volgens Dooyeweerd (a.w. p.59) is so 'n klassifikasie, in ooreenstemming met sy beginsel van uitsluiting van antinomieë, altyd moontlik, want " .... die waarheid is 'n eenheid .... antinomieë ontstaan slegs ten gevolge van foutiewe wetenskapsvorming".

'n Wyer of groter (aan die anderkant 'n nouer of enger) omvang van ' $n$ individu se beweging op die psigologies breedte-dimensie impliseer in sigself niks "goed" of "sleg" nie. Die voordeel of nadeel daarvan sal afhang van die vereistes of eise van die bepaalde omgewing (beroeps of andersins) waarin die individu moet optree of funksioneer.

Die breedte-konstruk sou ook empiries omlyn moet word. Bepaalde verbande tussen die omvang van beweging op die breedte-dimensie en sekere gedragswyses sou dus 
gehipotetiseer moet word en empiries getoets word. Eers dan sou gekonstateer kon word dat omvang van beweging op die breedte-dimensie (omvang van besigwees met die kosmiese modaliteite) 'n bepaalde gedragskonstruk is wat 'n verskeidenheid van gedragswyses saambind en verklaar.

\section{Die hoogte-dimensie}

Soos wat fisiese ruimte ook deur 'n hoogte-dimensie beskryf word so ook word die psigologiese ruimte onder andere deur " $n$ hoogte-dimensie afgebaken. Die mens se ervaring van die fisiese hoogte-dimensie het besondere kenmerke. Breedte en diepte is begrippe van ' $n$ 2-dimensionele vlak waarop die individu kan beweeg. Hy beweeg vorentoe (diepte) of na links of regs (breedte). Die kind raak dus vertroud met hierdie twee dimensies want hy beweeg fisies daarin. In die hoogte-dimensie kan hy beswaarlik in beweeg. Enige hoogteervaring wat daar wel mag wees is kortstondig van aard byvoorbeeld deur van hoogtes af te val of te gly; maar dit is nie 'n natuurlike ervaring nie. Die hoogte-dimensie is dus van kleins af vir die kind grootliks 'n fisies geslote dimensie.

Psigologies gesproke kan die mens vryer in die hoogte-dimensie beweeg. Hy kan hom indink in bv. die "ervaring" wat die voel of die ruimteskip moet hê om hoog en weg van die fisiese konkrete wêreld te beweeg. Die psigologiese beweging in die hoogte-dimensie is dus 'n beweging weg van die fisiese/konkrete. Dit is 'n relatief vreemde ervaring waar nie gesteun kan word op fisiese ankerpunte nie. Gebondenheid aan die konkrete/fisiese word nie hier ervaar nie. Dit impliseer 'n vryer, maar dan ook 'n enigsins abstrakte (weg van die konkrete) ervaring.

Vir die pasgeborene en klein kind lê die onbereikbare, fisiese bokant hom, op die hoogte-dimensie. Hierdie iets is aanvanklik die moeder en later ook ander volwassenes wat steeds bokant hom "stellinginneem" in die fisiese ruimte. Die begrip hoogte word mettertyd geassosieer met iets bokant (fisies) iets onbereikbaar (fisies) iets voordelig, anders, beter, nognie-verstaanbaar, andersfunksionerend en anderservarend. Die invloed van die fisies groter, sterker, hoër volwassene op die klein kind is 'n tema wat in die ontwikkelingsielkunde gereeld aandag kry. Die klein kind se besondere waarneming van sy fisies groter ouer en die effek wat dit op die selfbeeld het wat die kind in die vroegste lewensjare hieruit bou, word bv. treffend beskryf in die Trans-aksieanalise-leer van Harris (1969). Die onbetwisbare, soms onverstaanbare, ontasbare, dikwels onverklaarbare en onbegrypbare kom van 'n bron (die volwassene) wat inderwaarheid in die fisiese ruimte bokant die kind gesetel is. 
Hierdie onbereikbare (in fisiese terme) skakel mettertyd oor tot die begrip van moeilikbereikbaarheid, andersfunksionerendheid op psigologiese vlak. Die parameters van die fisiese hoogte-dimensie word so oorgedra en verwerk as parameters van die psigologiese hoogtedimensie. Moeilikbereikbaarheid, moeilikverstaanbaarheid, andersfunksionerendheid, abstraktheid, word dus alger parameters wat die psigies hoogte-dimensie definieer. Abstraktheid blyk die mees primêre kwaliteit van die hoogte-dimensie te wees. Abstraktheid in denke; funksionering dus op 'n "ongewone" minder voor-die-handliggende vlak. Abstraktheid verwys hier egter nie slegs na syferberedenering nie of na konsep- of simboolmanipulering nie. Dit verwys ook na die mate waarin beginsels in enige situasie (ook bv. menseverhoudings) gesoek en gedefinieer word en waarvolgens optredes en handelinge dan beplan en uitgevoer word.

Die vermoë om weg te kom van die konkrete, om dus die omgewinglike te abstraheer en die wette (beginsels) te identifiseer wat vir die konkrete geld, sal van individu tot individu verskil.

Die hoogte-dimensie, soos alle ander dimensies, veronderstel 'n kontinuum wat strek van 'n neiging om te werk met konkrete, liniêre begrippe tot 'n neiging by die mens om te werk met abstrakte nie-lineêre konsepte. Die veronderstelling is verder (soos ook ten opsigte van ander dimensies) dat ' $n$ bepaalde individu sal neig om op slegs 'n sekere gedeelte van die dimensie of kontinuum te funksioneer. 'n Bepaalde gewoonte-funksionering of styl is hier ter sprake. Dit impliseer verder dat 'n individu se posisie van gewoontefunksionering op die dimensie bepaal kan word.

Die hoogte-dimensie sou ook empiries omlyn moet word. Dit veronderstel die ontwikkeling van 'n meetinstrument waarvolgens 'n individu se posisie op die hoogtedimensie geïdentifiseer kan word en wat dan verder in verband gebring behoort te word met reeds bekende gedragsverskynsels wat logies of intuïtief deur sekere posisies op die hoogtedimensie verklaar kan word.

\section{Die tydsdimensie}

Die mens leef binne 'n fisiese ruimte en in hierdie ruimte ervaar hy homself as die middelpunt. Voorwerpe rondom hom neem 'n vaste verhouding teenoor mekaar en teenoor hom in. Die verhouding is staties en absoluut.

Wanneer die individu fisies beweeg, raak die verhouding tussen voorwerpe in sy fisiese ruimte en tussen homself en daardie voorwerpe dinamies en relatief. Beweging impliseer 
daarom relatiwiteit. Sonder beweging is daar geen sprake van 'n relatiewe verhouding tussen objekte in 'n fisiese ruimte nie. Beweging impliseer egter ook tydsverloop. Sonder tydsverloop is daar nie beweging nie. Dit is dus tydsverloop wat die relatiwiteit van voorwerpe en gebeure bepaal. Waar beweging (groei/ontwikkeling/verandering) die basiese kenmerke van lewe self is, en beweging tydsverloop veronderstel, word tydsverloop gepostuleer as dié mees fundamentele ervaring en gewaarwording van die mens. (Die dier bv. sou hierdie tydsverloop nie kan konseptualiseer nie, maar die diereryk word nogtans gereguleer deur die konsekwensies en noodwendigheid daarvan.) Tydsbelewenis en die ontwikkeling van 'n bepaalde oriëntasie tot tyd kom inderwaarheid neer op lewe-belewenis en 'n oriëntasie tot lewe.

Tydsbelewenis sou kon verskil van mens tot mens en dus sal die oriëntasie tot tyd wat daaruit ontwikkel, individuele verskille toon. Soos wat meeste menslike eienskappe geneties en omgewingsbepaald is, en dus individuele verskille toon, kan verwag word dat dieselfde vir tydoriëntasie sal geld. Die genetiese en omgewinglike bepaaldheid van tydoriëntasie veronderstel verder 'n differensiële ontwikkeling van tydsbegrip en oriëntasie (soos studies met kinders - Piaget, 1955 - ook aandui). In die lewe in die algemeen en in die beroepslewe in die besonder, is die erkenning en benutting van differensiële vermoëns en eienskappe die fondament waarop voortbestaan en oorlewing gebou word.

Die wetenskaplike bestudering en meting van tydoriëntasie as 'n differensiële vermoë of eienskap en verder as 'n (die mees?) fundamentele oriëntasie tot die lewe self sou daarom 'n besondere deurbraak kon lewer in die soeke na 'n beter begrip en verklaring van menslike gedrag.

Omdat die lewe as sodanig beweging (tydsverloop) veronderstel en die mens van nature deel is van hierdie beweging(ontwikkeling/verandering) hierdie tydsverloopproses, is tydoriëntasie van selfsprekend 'n basiese aanpassingsmeganisme. Verder, omdat dit 'n belangrike aanpassingsmeganisme is, hou die mens van nature "rekord" van welke beweging (verandering ens.) daar in die verlede was, huidig aan die gang is en in die toekoms kan plaasvind. Die mens is dus in kontak met die verlede, hede en toekoms. Daarop baseer hy sy tydoriëntasie wat as voortbestaansmeganisme dien. Sy tydoriëntasie is dus verlede-, hede- en toekomsgerig in sy deurlopende proses van aanpassing.

Waar tydoriëntasie individuele verskille veronderstel, kan verwag word dat die unieke omgewingsinvloede waaraan elke individu blootgestel word, die kenmerke van sy besondere tydoriëntasie sal bepaal. Hierdie invloede sou histories van aard kan wees sowel as 
kontemporêr. Dit impliseer dat tydoriëntasie nie 'n vaste eienskap is nie, maar dat dit (binne grense) van tyd tot tyd kan verander - hoewel die historiese invloede oorwegend swaarder sal weeg sodat daar tog van 'n min of meer vaste oriëntasiestyl gepraat kan word.

Waar die individu die middelpunt binne 'n statiese, absolute ruimte uitmaak (indien so 'n staat gekonseptualiseer kan word) verskuif hierdie posisie wanneer tydsverloop ter sprake kom. Die mate waarin 'n individu hom dus nie as die middelpunt van gebeure sien nie, maar as ' $n$ bewegende punt in 'n konstellasie van veranderende, bewegende objekte, tot daardie mate is hy in staat om by tydsverloop, beweging, ontwikkeling, verandering aan te pas.

Waar tydoriëntasie onder andere aan omgewingsinvloede onderworpe is en dus ontwikkeling (verandering) ondergaan sou dit verwag kan word dat verskillende ouderdomsgroepe as groepe verskillende tydoriëntasie sal hê. Die homogeniteit van sodanige oriëntasiesgroepe kan heelwaarskynlik sinkroniseer met erkende lewensfases (soos byvoorbeeld dié omlyn deur Waterink of Bühler).

Indien verskillende lewensfases ook verskillende tydoriëntasies impliseer, het dit verrykende gevolge vir beroepskeuse en beroepsaanpassing. Dit maak ook die formulering van 'n bepaalde verhouding moontlik tussen kronologiese ouderdom (of lewensfase bereik) en tydoriëntasie-ouderdom; wat dit verder moontlik maak om 'n bepaalde individu met betrekking tot tydoriëntasie in verhouding tot sy lewensfasegroep te plaas.

Op hierdie stadium van die formulering van die 4-D teorie word daar nie 'n poging aangewend om die verskillende oriëntasies tot tyd te omlyn nie. So 'n omlyning behoort te geskied teen die agtergrond van reeds bestaande navorsing op hierdie terrein. Die formulering sal egter uiteindelik die beginsels soos in bestaande paragrawe uiteengesit, moet bevredig.

\section{VALIDERING VAN DIE KONSTRUKTE VAN DIE 4-D TEORIE}

Die vier dimensies van die 4-D teorie word gesien as basiese konstrukte van menslike gedrag en as sodanig hou dit verband (behoort dit verband te hou) met bepaalde gedragswyses - kognitief, konatief en konotatief. Hierdie "verband hou met" impliseer die validering of (beter) die logiese en empiriese omlyning van elk van die vier konstrukte.

Waar elke konstruk 'n basiese, hoogs abstrakte (d.w.s. moeilik operasioneeldefinieerbare) konsep van menslike gedrag is, is dit noodsaaklik dat dit, as 'n eerste stap in die valideringsproses, op 'n logies-rasionele vlak aan reeds bekende (dog minder omvattende) vorme 
van gedrag, soos bepaalde vaardighede, aanlegte, persoonlikheidseienskappe, gekoppel sal word. Op hierdie stadium behoort ook bepaalde verbande tussen elk van die konstrukte en enkele meetbare vorme van gedrag gehipotetiseer te word.

Die volgende stap sou wees om vir elk van die vier konstrukte 'n interne konstante meetmiddel te ontwikkel. Die formulering van items van sodanige meetmiddels sal gebaseer moet wees op die beskrywing van die aard van die konstrukte en op eie kennis wat opgedoen is in die logiese koppeling van die onderskeie konstrukte aan bekende, meetbare vorme van gedrag soos in die voorafgaande stap aangedui. Met betroubare meetinstrumente vir die verskillende konstrukte beskikbaar, kan die gehipotetiseerde verbande tussen die konstrukte en bepaalde meetbare vorme van gedrag empiries getoets word.

'n Verdere belangrike stap in die valideringsproses van die konstrukte sou wees om die posisie van bepaalde homogene beroepsgroepe, soos bv. onderwysers, musici of ingenieurs op elk van die dimensies (konstrukte) vooruit te voorspel. Die lede van so 'n beroepsgroep word dan m.b.v. die meetinstrumente op bepaalde posisies op die onderskeie dimensies geplaas. Indien hierdie voorspelde posisies en die waargenome posisies ooreenstem, sou dit 'n addisionele ondersteuning vir die handbaarheid van die teorie wees.

Bostaande is slegs enkele hoofmomente van die valideringsproses. Verdere stappe soos bv. uiteengesit deur Helmstadter (1964, pp.138-145) behoort in die valideringsproses oorweeg te word.

\section{ENKELE PRAKTIESE AANWENDINGSMOONTLIKHEDE}

Die 4-D-benadering sou moontlik ook van nut kon wees in die beroeps- en bedryfslewe. Hierdie moontlike bruikbaarheid hang nou saam met die definiëring van normgroepe waarteen individue se posisie in die psigologiese ruimte gespieël kan word.

Normgroepe word gewoonlik gedefinieer met 'n bepaalde doel voor oë. Indien die doel sou wees om byvoorbeeld 'n individu se potensiaal vir 'n bepaalde soort beroep te skat, sou sy posisie in die psigologiese ruimte geprojekteer kon word op ' $n$ assestelsel wat gekonstrueer is vir 'n groep suksesvolle beoefenaars van daardie beroep. Hoe nader hy aan die kern van daardie besondere sfeer kom, hoe groter is sy kanse om ook suksesvol te wees in die onderhawige beroep. 
Dat hierdie benadering van toepassing gemaak kan word op konseptueel enige moontlike situasie, spreek vanself. Daar word van die veronderstelling uitgegaan dat sekere beroepe (werke, posisies) sekere vermoëns, eienskappe, vaardighede, vereis van die suksesvolle applikant en dat hierdie vermoëns, eienskappe, vaardighede gereduseer kan word tot die vier dimensies soos omskryf. Elke beroep sou dus geklassifiseer kan word (indien nie eksak nie, dan wel by benadering), ooreenkomstig die vier dimensies. Elke beroep (werk, posisie) vereis byvoorbeeld 'n bepaalde tydoriëntasie van sy werknemers, sowel as 'n bepaalde kombinasie van psigologiese diepte, breedte en hoogte ('n bepaalde posisie in die psigologiese ruimte dus). Indien beroepe (werke, posisies) volgens hierdie stelsel omskryf kan word en elke (voornemende) werknemer of posbekleër daarvolgens geklassifiseer kan word, blyk die bymekaarbring van die individu en sy pos (hetsy by wyse van keuring, plasing, opleiding of ontwikkeling) nie so moeilik te wees nie. Fundamenteel kom dit neer op 'n stelsel waarvolgens die eise wat 'n beroep stel en die eienskappe waaroor 'n individu beskik, objektief en in dieselfde terme omskryf kan word.

Die aanwendingsmoontlikhede van so 'n stelsel is legio en voor-die-hand-liggend. Trouens, alle sielkundige meetmiddels soos gebruik in die beroepswêreld en alle werkontleding en -evalueringsisteme is afgestem op die bymekaarbring van werk en werknemer. In die Bedryfsielkunde sal bogenoemde benadering veral gevolg word in personeelkeuringsituasies. Wanneer die probleem egter een van personeelplasing of beroepsleiding is, verg die gebruik van die 4-D-sisteem 'n konseptuele ommeswaai. In dié geval word die individu se "prestasies" op die vier dimensies gebruik om die kern van die sfeer te definieer en die bepaalde beroep of beroepe ter sprake se gemiddeldes (eintlik suksesvolle individue in die beroep se gemiddeldes) word gebruik om die beroepe se posisies in die psigologiese ruimte wat so gedefinieer is, aan te dui. Die beroep wat die naaste aan die individu (kern van die psigologiese ruimte ) lê, sou beskou kon word as dié een waarin hy die beste behoort te vaar. Hierdie afstande kan natuurlik weer eens bereken word m.b.v. die formule vir afstande in 'n sfeer soos voorheen uiteengesit.

Soos in die inleidende opmerkinge deurskemer, is die 4-D teorie 'n poging om 'n eenvoudige klassifikasieteorie daar te stel wat kan dien om 'n greep te kry op 'n oorvloed van (dikwels) uiteenlopende navorsingsresultate i.v.m. menslike gedrag. Op die eenvoud van die teorie word daar 'n hoë premie gestel. Indien dít nie bewaar word nie, en in toekomstige verdere ontwikkeling as norm dien nie, beantwoord dit nie aan die doel waarvoor dit geformuleer is nie. Ten einde hierdie eenvoud verder uit te werk, kan die volgende gedagte 
mettertyd (wanneer die nodige informasie ingewin is) empiries geverifieer word; naamlik dat daar moontlik 'n konstante verhouding bestaan tussen die vier dimensies van menslike gedrag. Dit mag wees dat individue wat op 'n sekere dimensie(s?) 'n bepaalde posisie inneem, neig om bepaalde posisies op die ander dimensies in te neem. Indien dit so sou wees, maak dit die tipering van menslike gedrag moontlik en kan daar langs hierdie weg selfs uitgekom word by 'n min of meer waterdigte sinvolle tipologie.

Die uitwerk van die 4-D teorie met al die konseptuele konsekwensies en vertakkings daarvan is 'n langtermyn opdrag. Die eerste en belangrikste daarvan is die formulering en empiriese fundering van die vier basiese konstrukte wat dit veronderstel. So 'n formulering sou uiteraard moet geskied in die lig van reeds bestaande kennis aangaande vorme van menslike gedrag wat min of meer met die konstrukte verband hou. Die enigste bepaling is dat die fundamentele uitgangspunte en kriteria onderliggend aan elkeen van die konstrukte of dimensies nie geweld aan gedoen moet word nie.

\section{OPSOMMING}

Riglyne vir die ontwikkeling van 'n 4-dimensionele teorie van menslike gedrag word geformuleer en bespreek. Die 3 ruimtelike dimensies naamlik hoogte, breedte en diepte en tyd word as vertrekpunt geneem en die psigiese analoë daarvan word as fundamentele konstrukte van menslike gedrag geformuleer en logies uitgebou. Die psigologiese ruimte (sfeer) wat deur die 3 psigiese dimensies (asse) beskryf word en die mens se tydoriëntasie word as basis gebruik vir die tipering en klassifisering van menslike gedrag. Enkele praktiese aanwendingsmoontlikhede en riglyne vir die verdere ontwikkeling en validering van die teorie word aan die hand gedoen.

\section{VERWYSINGS}

Boring, E.G. A History of Experimental Psychology. New York: Appleton-Century-Crofts, 1950.

Bühler, Charlotte. Der Menschliche Lebenslauf als Psychologisches Problem. Göttingen: Verslag für Psychologie, 1959.

Hall, C.S. en Lindzey, G. Theories of Personality. New York: Wiley, 1957.

Harris, T.A. I'm O.K.-You're O.K. New York: Avon, 1969.

Helmstadter, G.C. Principles of Psychological Measurement. Englewood Cliffs, N.J., Prentice-Hall, 1964.

Herrnstein, R.J. en Boring, E.G. A Source Book in the History of Psychology. Cambridge, Mass.: Harvard U. Press, 1966.

Marx, M.H. Theories in Contemporary Psychology. New York: MacMillan, 1966. 
Piaget, J. The development of time concepts in the child. In Hoch, P.H. en Zubin, J. (Reds.) Psychopathology of Childhood. New York: Grune and Stratton, 1955.

Spence, K.W. The nature of theory construction in contemporary psychology. Psychological Review, 1944, 51,47-68.

Stoker, H.G. Beginsels en Metodes in die Wetenskap. Johannesburg: De Jongh, 1969.

Thouless, R.H. Some problems of terminology in psychological theory. British Journal of Psychology, 1949, 40, 41-66.

Tyler, Leona, E. The Psychology of Human Differences. New York: Appleton-CenturyCrofts, 1965.

Wijngaarden, H.R. Hoofproblemen der Volwassenheid. Utrecht: Bijleveld, 1959. 